\title{
Analysis Implementing Obstacles of State Elementary School 2 Kebumen in The 2013 Curriculum
}

\section{Hanif Imadudin, Astika Krisnawati, Syifa' Lana, Kartika Chrysti Suryandari}

Sebelas Maret University

imadudin206@student.uns.ac.id

\section{Article History}

accepted 24/09/2019

approved 01/10/2019

published 01/12/2019

\begin{abstract}
This study was intended to see obstacles in implementing the 2013 curriculum by elementary school teacher 2 Kebumen. This study uses qualitative descriptive assessment methods. The subject of this study is 6 elementary school teachers 2 Kebumen made up of 6 class teachers. Data collection using angers and interviews. Studies show that the obstacles that elementary school teacher 2 Kebumen experienced in implementation of the 2013 that is in the plannin phase, implement phase, and evaluation phase. Obstacles include learning preparation, slection and media lerning making, insight teacher, cross-loading of lessons in thematic learning, and It literacy.
\end{abstract}

Keywords: 2013 curriculum, implementation obstacles.

\begin{abstract}
Abstrak
Penelitian ini bertujuan untuk mengidentifikasi hambatan-hambatan dalam mengimplementasikan Kurikulum 2013 yang dialamai guru SD Negeri 2 Kebumen. Penelitian ini menggunkana metode penelitian deskriptif kualitatif. Subjek dalam penelitian ini ialah 6 guru SD Negeri 2 Kebumen yang terdiri dari 6 orang guru kelas. Pengumpulan data menggunakan instrumen angket dan wawancara. Hasil penelitian menunjukkan bahwa hambatan-hambatan yang dialami guru SD Negeri 2 Kebumen dalam implementasi kurikulum 2013 yaitu pada tahap perencanaan, tahap pelaksanaan, dan tahap evaluasi. Hambatan - hambatan tersebut meliputi persiapan pembelajaran, pelaksanaan pembelajaran, pemilihan dan pembuatan media pembelajaran, pemahaman guru, pemaduan antarmuatan pelajaran dalam pembelajaran tematik, pemilihan metode pembelajaran dan penguasan teknologi informasi.
\end{abstract}

Kata kunci: kurikulum 2013, hambatan pelaksanaan.

Social, Humanities, and Education Studies (SHEs): Conference Series https://jurnal.uns.ac.id/shes

p-ISSN 2620-9284

e-ISSN 2620-9292 


\section{PENDAHULUAN}

Perubahan kurikulum dilatarbelakangi adanya perubahan zaman khususnya terkait sistem pendidikan. Kurikulum merupakan seperangkat rencana dan pengaturan mengenai tujuan, isi, dan bahan pelajaran serta cara yang digunakan sebagai pedoman penyelenggaraan kegiatan pembelajaran untuk mencapai tujuan pendidikan nasional (UU No.20 Tahun 2003). Agar senantiasa sesuai dengan perkembangan zaman, kurikulum senantiasa berubah. Perubahan dan pengembangan Kurikulum 2013 diharapkan dapat menjadi jawaban untuk meningkatkan kompetensi sumber daya manusia menghadapi globalisasi dunia. Pada dasarnya kurikulum 2013 berfungsi untuk menyiapkan generasi yang handal di masa depan. Tujuan utama dari penerapan kurikulum 2013 adalah agar siswa memiliki bekal ketrampilan proses. Konsekuensinya manusia Indonesia tidak mampu bersaing jika tidak segera menerapkan kurikulum 2013. Pengembangan Kurikulum 2013 bertujuan agar tercapai kompetensi yang seimbang antara keterampilan, pengetahuan, dan, sikap, serta pembelajaran yang menyeluruh dan menyenangkan. Hal ini sejalan dengan amanat Undang-Undang No. 20 Tahun 2003 tentang Sistem Pendidikan Nasional, pada penjelasan pasal 35 dinyatakan bahwa kompetensi lulusan merupakan kualifikasi kemampuan lulusan yang mencakup sikap, pengetahuan, dan keterampilan sesuai dengan standar nasional yang telah disepakati (Yusuf, 2013).

Faktor-faktor yang menjadi alasan perubahan dan pengembangan Kurikulum 2013 yaitu: tantangan masa depan, kompetensi masa depan, fenomena sosial yang mengemuka, dan pendapat masyarakat luas yang menganggap bahwa pendidikan hanya mengutamakan aspek kognitif. Perubahan dan pengembangan Kurikulum 2013 merupakan bagian dari strategi meningkatkan capaian pendidikan. Pada Kurikulum 2013 aspek sikap menjadi prioritas utama karena disadari bahwa berbagai permasalahan sosial, ekonomi, dan hukum bersumber dari lemahnya sikap masyarakat. Pengetahuan dan keterampilan yang baik pada masyarakat, namun mereka tidak memiliki sikap yang baik akan merusak tatanan masyarakat. Pembentukan aspek sikap tersebut oleh pemerintah disebut sebagai pembentukan karakter masyarakat seperti dalam wujud kejujuran, tanggung jawab, integritas, toleransi, dan lain sebagainya.

Perubahan kurikulum berarti perubahan bahan ajar serta pendekatan yang digunakan dan guru merupakan faktor utama pendukung perubahan kurikulum tsb. Guru harus membuat persiapan yang baru menyesuaikan kurikulum yang berubah. Guru merupakan sumber daya manusia dalam implementasi Kurikulum 2013. Sumber daya manusia yang digunakan akan menentukan implementasi dan keberhasilan kebijakan. Hal ini kiranya sejalan dengan pendapat Van Meter dan Van Horn (Hill dan Hupe, 2009:4647).

Dalam konteks Indonesia rencana memunyai sumbangan sebesar $20 \%$ terhadap keberhasilan suatu kebijakan, implementasi memunyai sumbangan sebesar $60 \%$, sisanya $20 \%$ adalah bagaimana mengendalikan implementasi (Tilaar dan Rian Nugroho, 2008:211 dalam Krissandi dan Rusmawan, 2015). Oleh karena itu, implementasi merupakan hal yang paling berat dalam keberhasilan suatu kebijakan. Hal ini dikarenakan masalah yang tidak dijumpai secara teoretis dapat muncul dalam implementasi di lapangan.

Oleh karena pentingnya mengetahui kesiapan guru dalam menerapkan Kurikulum 2013. Perubahan dan pengembangan Kurikulum 2013 saat ini telah mencapai tahap implementasi di seluruh daerah di Indonesia, yang pada hakikatnya telah memberikan gambaran hasil pelaksanaan Kurikulum 2013 tersebut diterapkan. Faktor-faktor pendukung dan penghambat maupun langkah-langkah yang dapt dilakukan supaya mengatasi kendala dalam pelaksanaaan. Berdasarkan hal tersebut, diperlukan suatu studi secara komprehensif. Studi ini juga merupakan upaya untuk 
memberikan justifikasi terhadap signifikansi hasil uji coba Kurikulum 2013 yang telah dilakukan di lapangan.

\section{METODE}

Metode penelitian yang digunakan berupa deskriptif kuanlitatif. Penelitian deskriptif kualitatif menurut Kriyantono (2007) dalam Akhmad tahun 2015 yakni teknik yang menjabarkan data yang diperoleh melalui mencatat dan melihat sebanyakbanyaknya informasi yang didapat, sehingga mampu memberikan gambaran nyata dan menyeluruh terhadap keadaan sebenarnya. Penelitian deskriptif ditujukan untuk menjabarkan kejadian-kejadian yang ada baik itu keadaan alami maupun buatan manusia (Linarwati, dkk. : 2016). Miles dan Huberman (1994) dalam Gumilang. G.S (2016) menyatakan secara umum ada tiga cara yang dapat digunkan untuk menganalisis data kualitatif yaitu, reduksi data, penyajian data dan penarikan kesimpulan. Reduksi data adalah pemusatan perhatian dan penyederhanaan data yang ada di lapangan. Penyajian data adalah penyusunan data yang terkumpul sehingga memungkinkan menarik kesimpulan dan mengambil tindakan. Penarikan kesimpulan merupakan usaha menguji atau mengecek kembali arti, penjelasan, atau sebab-akibat sehingga mampu mendeskripsikan suatu fenomena yang sebelumnya masih belum belum jelas.

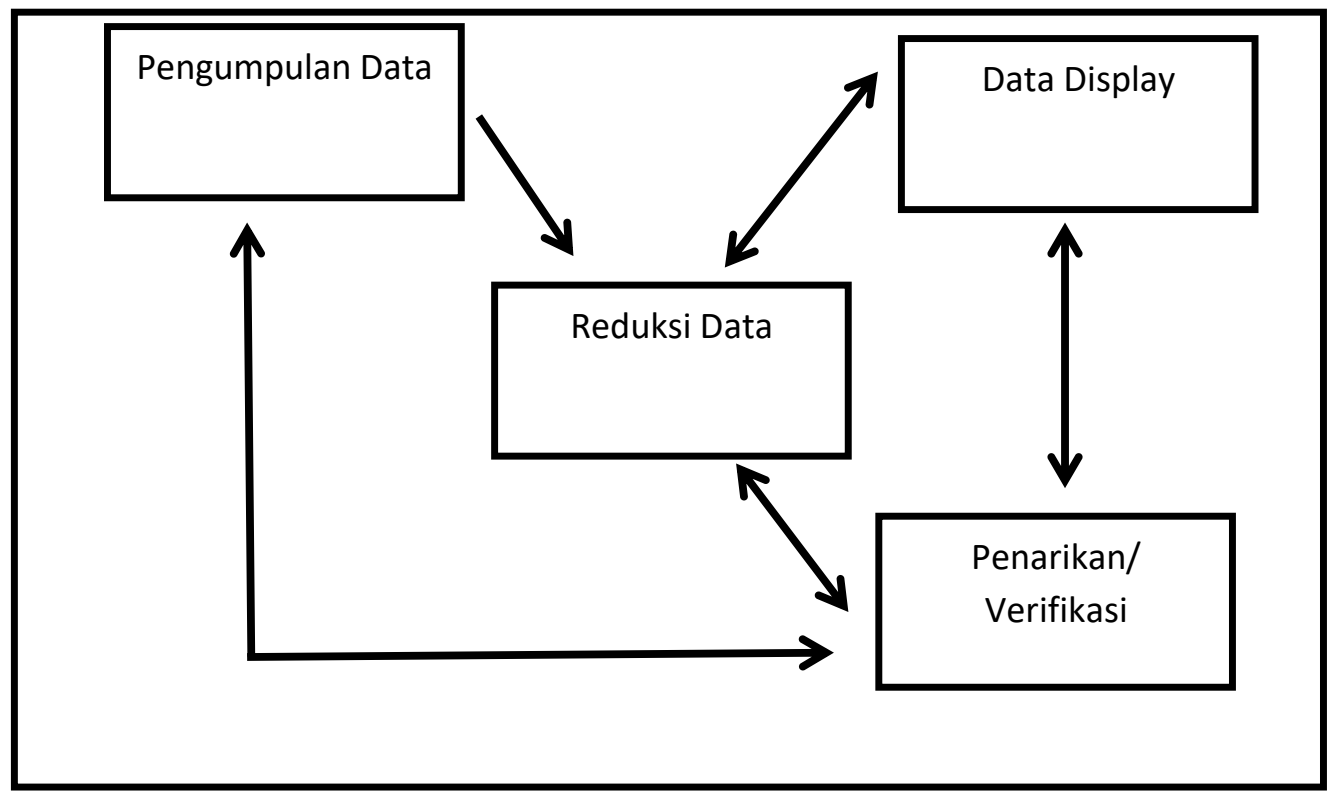

Jenis data yang digunakan merupakan data primer dimana peneliti mendapatkan data langsung melalui wawancara dengan narasumber. Sumber data berupa wawancara dan penyebaran angket terhadap guru kelas.

\section{HASIL DAN PEMBAHASAN}

Pelaksanaan kurikulum 2013 mulai diterapkan secara bertahap pada tanggal 15 Juli 2013. Menurut Kementerian Pendidikan dan Kebudayaan (Kemdikbud) akan ada bonus demografi bagi Indonesia pada tahun 2010-2035 dimana perlu dipersiapkan generasi emas (Tim Penyusun Modul PLPG, 2013). Penerapan dilakukan secara bertahap, dimana pada awalnya diterapkan di kelas 3 dan 6. Tahun ajaran 2019/2020 
kurikulum ini dilakukan penerapan yang menyeluruh bagi semua kelas. Hal tersebut juga berlaku di SD N 2 Kebumen.

Kurikulum 2013 bertujuan untuk membentuk karakter siswa sehingga mampu berkontribusi bagi masyarakat, bangsa, dan di hadapan dunia serta mampu memecahkan masalah sosial. Mulyasa (2013) berpendapat bahwa sangat penting dilakukan sosialisasi pada implementasi kurikulum,agar semua pihak paham dengan tugas dan fungsinya. Guru adalah salah satu factor penting yang menentukan keberhasilan diterapkannya kurikulum 2013. Guru berperan sebagai perencana sekaligus pelaksana dalam pembelajaran kurikulum 2013 sehingga guru dituntut memahami secara mendalam kurikulum 2013. Pada kenyataannya menurut penelitian yang dilakukan Melati dan Utanto (2016) sebagian besar guru kurang paham terhadap pelaksanaan kurikulum 2013. Selain itu, menurut pendapat Nurmalasari (2015) mengatakan bahwa perubahan kurikulum KTSP menjadi kurikulum 2013 yang sangat besar menyebabkan kurang siapnya guru dan guru belum sepenuhnya memahami maksud daripada kurikulum 2013 dan cara pengimplementasiannya.

Berdasarkan hasil wawancara dan pembagian angket kepada Guru SD Negeri 2 Kebumen. Sebagian besar guru telah memahami pengimplementasiannya kurikulum 2013. Akan tetapi, masih ada beberapa hambatan yaitu meliputi persiapan pembelajaran, pelaksanaan pembelajaran, pemilihan dan pembuatan media pembelajaran, pemahaman guru, pemaduan antarmuatan pelajaran dalam pembelajaran tematik, pemilihan metode pembelajaran dan penguasan teknologi informasi.

Dari angket yang kami bagikan, pada tahap persiapan masih banyak guru yang mengandalkan RPP dari sumber internet dibandingkan membuat sendiri. Hal ini sejalan penelitian yang dilakukan oleh Kastawi, dkk (2017) yang menyatakan bahwa guru SD belum memahami pembelajaran tematik sehingga guru belum mampu membuat persiapan pembelajaran secara mandiri. Banyaknya administrasi yang harus diurus oleh guru juga menghambat guru untuk dapat membuat RPP secara mandiri. Seperti penelitian yang dilakukan oleh Ningrum dan Ahmad (2013) guru harus melengkapi banyak administrasi dan RPP harus mencantumkan tiga pendekatan, waktu yang dimiliki guru untuk menyusun dan melakukan persiapan menjadi sangat terbatas.

Hambatan lain yang dialami guru ialah dalam hal metode pembelajaran. Menurut hasil wawancara yang sudah dilakukan, guru jarang memberikan variasi metode pembelajaran bahkan masih sering menggunakan metode konvensional. Bahkan dari hasil angket yang dibagikan banyak guru yang kesulitan untuk menerapkan metode saintific. Hal tersebut sependapat dengan penelitian yang dilakukan oleh Krissandi dan Rusmawan (2015) bahwa guru-guru di Indonesia belum siap dalam melaksanakan pendekatan saintific, karena sejak dulu mayoritas pembelajaran menggunakan metode ceramah. Metode saintific yang diharapkan mampu menumbuhkan keaktifan pada siswa malah seringkali membingungkan karena ketidakmampuan guru untuk menerapkan dalam pembelajaran. Menurut salah seorang guru yang kami wawancarai, menyatakan kurang tertarik mempelajari metode lainnya karena terlalu banyak variasi sehingga sulit untuk dipahami.

Penggunaan media dan teknologi pembelajaran yang dilakukan oleh guru SD Negeri 2 Kebumen masih belum maksimal. Kurangnya fasilitas yang disediakan serta kemampuan guru dalam bidang teknologi yang belum maksimal menjadi hambatannya. Data yang kami temukan di SD Negeri 2 Kebumen menunjukkan kurangnya fasilitas yaitu: hanya ada 3 buah LCD untuk 6 kelas, printer ada 1 buah, laptop hanya ada 2 buah, pengeras suara hanya ada 5 buah, jangkauan dan kecepatan wi-fi yang terbatas menyebabkan tidak bisa memaksimalkan pembelajaran. Bahkan apabila, semua perangkat digunakan listrik akan padam. 
Pada pembelajaran tematik tentunya menggabungkan beberapa mata pelajaran. Namun, dalam pelaksanaannya guru masih kesulitan dalam mengaitkan beberapa mata pelajaran tersebut disebabkan karena perlu adaptasi yang luar biasa sulit dalam mengimplementasikan pembelajaran tematik. Guru harus memiliki kemampuan memadukan muatan pelajaran menjadi satu dan mengalir sepanjang pembelajaran tanpa terfragmentasi (terbagi-bagi per mata pelajaran) (Krissandi dan Rusmawan : 2015). Sependapat dengan Maisyaroh, dkk (2014) bahwa guru masih kesulitan melaksanakan pembelajaran secara tematik, serta guru sulit untuk memahami strategi penanaman konsep tanpa bantuan alat peraga yang sesuai. Guru kesulitan meningkatkan antusiasme siswa karena terbiasa dengan hanya menjelaskan teori.

Hambatan - hambatan lainnya yang dialami oleh guru ialah dalam hal evaluasi pembelajaran. Guru merasa kesulitan dalam memantau tingkat kemampuan siswa, karena penilaian harus dilakukan secara bertahap pencatatan yang tidak teratur menghambat pemantauan tingkat kemampuan siswa. Karena tidak setiap hari pencatatan dapat dilakukan serta kesibukan yang dialami guru. Jam pembelajaran yang padat menyebabkan guru kesulitan dalam mencari waktu pengayaan dan waktu remidi. Tidak setiap hari evaluasi dapat dilakukan. Pada kurikulum 2013 penyusunan evaluasi harus didasarkan setiap KD mata pelajaran, sehingga penilaian hasil belajar yang dimiliki siswa tidak mampu untuk diukur secara langsung dalam satu hari. Sebagai contoh ketika ulangan guru mengalami kesulitan dalam membuat soal tematik yang di dalamnya terdapat banyak sekali muatan pelajaran (Krissandi dan Rusmawan : 2015).

Berkaitan dengan hambatan-hambatan yang ditemukan di SD Negeri 2 Kebumen, maka pemerintah khususnya dinas pendidikan melakukan pelatihan secara berkala agar kemampuan guru meningkat dalam menerapkan kurikulum 2013. Pelatihan dilakukan berupa: pelatihan penyusunan perencanaan pembelajaran yang tepat, pelatihan teknologi informasi, sosialisasi secara berkala penggunaan metode pembelajaran, serta pelatihan pembuatan media. Selain itu, pemberian dukungan dengan melengkapi fasilitas sekolah seperti: buku pembelajaran, perangkat teknologi, serta media pembelajaran.

\section{SIMPULAN}

Berdasarkan pada temuan dan pembahasan sebelumnya, dapat ditarik kesimpulan berkaitan dengan implementasi kurikulum 2013 di SD Negeri 2 Kebumen. Penelitian ini secara umum menguatkan penelitian terdahulu, bahwa implementasi kurikulum 2013 masih terdapat hambatan - hambatan yang menyebabkan tidak bisa berjalan secara maksimal. Hasil penelitian menunjukkan bahwa hambatan-hambatan yang dialami guru SD Negeri 2 Kebumen dalam implementasi kurikulum 2013 yaitu pada tahap perencanaan, tahap pelaksanaan, dan tahap evaluasi. Hambatan hambatan tersebut meliputi persiapan pembelajaran, pelaksanaan pembelajaran, pemilihan dan pembuatan media pembelajaran, pemahaman guru, pemaduan antarmuatan pelajaran dalam pembelajaran tematik, pemilihan metode pembelajaran dan penguasan teknologi informasi.

\section{DAFTAR PUSTAKA}

Akhmad, K. A. (2015) . Pemanfaatan Media Sosial Bagi Pengembangan Pemasaran UMKM (Studi Deskriptif Kualitatif Pada Distro Di Kota Surakarta). Jurnal Duta 9(1), 43-53.

Gumilang. G.S (2016). Metode Penelitian Kualitatif Dalam Bidang Bimbingan Dan Konseling. Jurnal Fokus Konseling 2(2), 144-159.

Hill, M. and Hupe P. (2009) Implementing Public Policy. California: Sage Publication. Inc. 
Kastawi, dkk. (2017). Kendala dalam Implementasi Kurikulum 2013 di Jawa Tengah dan Strategi Penanganannya. Indonesian Journal of Curriculum and Educational Technology Studies. Vol 5 (2): 66-76.

Krisssandi \& Rusmawan. (2015). Kendala Guru Sekolah Dasar Dalam Implementasi Kurikulum 2013. Jurnal Cakrawala pendidikan Vol 24(3): 457-467.

Linarwati. (2016). Studi Deskriptif Pelatihan Dan Pengembangan Sumberdaya Manusia Serta Penggunaan Metode Behavioral Event Interview Dalam Merekrut Karyawan Baru Di Bank Mega Cabang Kudus. Journal of Management Vol 2 (2).

Maisyaroh, dkk. (2014). Masalah Guru Dalam Implementasi Kurikulum 2013 Dan Kerangka Model Supervisi Pengajaran. Jurnal Manajemen Pendidikan Vol 24(3): 213-220.

Melati, E.R., dan Utanto, Y. (2016). Kendala Guru Sekolah Dasar dalam Memahami Kurikulum 2013. Indonesian Journal of Curriculum and Educational Technology Studies, Vol 4(1): 1-9.

Mulyasa, E. (2013). Pengembangan dan Implementasi Kurikulum 2013. Bandung: PT Remaja Rosdakarya.

Ningrum \& Ahmad. (2013). Implementasi kurikulum 2013 di sekolah dasar. Jurnal managemen pendidikan Vol 24 (5) :416-423.

Tim Pengembang Modul PLPG. (2013). Modul PLPG. Yogyakarta: Universitas Sanata Dharma.

Yusuf, M. (2013). Mengantisipasi Perubahan Kurikulum 2013. Jurnal IImiah SPIRIT. Vol 13(1): 27-42. 